\title{
Opiate and Peptide Inhibition of Transmitter Release in Parasympathetic Nerve Terminals
}

\author{
D. Bruce Gray, Guillermo R. Pilar, and Maura J. Ford \\ The Department of Physiology and Neurobiology, University of Connecticut, Storrs, Connecticut 06268
}

\begin{abstract}
Somatostatin, morphine, and opioids inhibit transmitter release at intact neuromuscular junctions between ciliary ganglion neurons and the choroidal smooth muscle of the chick eye. Somatostatin and morphine, however, have no effect on release from terminals on the striated muscle target of the ciliary ganglion, the iris. In neuronal terminals of both the choroid and the iris, a high-affinity $\mathrm{Na}^{+}$-dependent choline uptake-mediated ACh synthesis is present at hatching. Both tissues exhibit a basal release of ${ }^{3} \mathrm{H}-\mathrm{ACh}$ which is potentiated severalfold during a 5 minute incubation in $55 \mathrm{~mm} \mathrm{~K} \mathrm{~K}^{+}$ Tyrodes. Fifty percent of the basal release and $100 \%$ of the stimulated release are $\mathrm{Ca}^{2+}$ dependent and probably mediated through $\mathrm{N}$-like voltage-dependent $\mathrm{Ca}^{2+}$ channels. Coincubation of the choroid with $10 \mu \mathrm{M}$ morphine sulfate blocks approximately $90 \%$ of the stimulated release. The same effect is seen with $100 \mathrm{nM}$ somatostatin, $10 \mu \mathrm{M}$ dynorphin, and $100 \mu \mathrm{M}$ met-enkephalin arginine phenylalanine. Preincubation of the excised choroid with pertussis toxin $(200 \mathrm{ng} / \mathrm{ml})$ reverses the inhibitory effects of both morphine and somatostatin. In contrast, ${ }^{3} \mathrm{H}$-ACh release from terminals in the striated iris is not affected by either morphine or somatostatin at micromolar levels. These results suggest that both opiate and somatostatin receptors are present in the choroid target and that they may act through a final common pathway to modulate ACh release via G proteins. Second messengers such as cyclic AMP or diacylglycerol do not appear to mediate these effects; neither increasing cAMP levels in terminals nor activation of protein kinase $C$ affects evoked release or its inhibition by morphine or other neuromodulators. It is unclear whether endogenous neuromodulation occurs in this system, although somatostatin-like immunoreactivity can be demonstrated in terminals of choroid neurons.
\end{abstract}

In the past several years, there has been a concerted effort to identify the chain of molecular events by which opiates and peptides modulate synaptic transmission. Although the effects of opiates on transmitter release were described over 30 years ago, recent studies have focused on the mechanism of action of

\footnotetext{
Received June 24, 1988; revised Sept. 19, 1988; accepted Oct. 20, 1988.

We thank Dr. L. Landmesser and Dr. J. Covault for their critical reading of this manuscript, Dr. A. Brown and Dr. J. Cooper for their suggestions and comments, and Ms. S. Putnam for her editorial assistance. The work described above was supported by NSF 8410581 , NIH 10338, and the University of Connecticut Research Foundation.

Correspondence should be addressed to Dr. D. Bruce Gray, Department of Physiology and Neurobiology, University of Connecticut, 75 N. Eagleville Rd. Room 415, Storrs, CI 06268.

Copyright (C) 1989 Society for Neuroscience $0270-6474 / 89 / 051683-10 \$ 02.00 / 0$
}

the peptides by recording single-channel activity (for $\mathrm{K}^{+}$and $\mathrm{Ca}^{2+}$ ) and determining the role of regulatory proteins in modifying channel activation (Logothetis et al., 1987; Yatani et al., 1987a). It has been demonstrated that various types of voltagesensitive $\mathrm{Ca}^{2+}$ and $\mathrm{K}^{+}$channels are involved in the modification of transmitter release by opiates and other peptides (Hescheler et al., 1987; Yatani et al., 1987a).

Morphine and opioid peptides are known to block cholinergic transmission by pre- and postsynaptic mechanisms in many preparations, including autonomic ganglia (Bornstein and Fields, 1979; Katayama and Nishi, 1984; Cherubini and North, 1985; Araujo and Collier, 1987). In synaptosomes from the electric organ of the Torpedo, $\mathrm{ACh}$ release, evoked by high $\mathrm{K}^{+}$and mediated by voltage-sensitive $\mathrm{Ca}^{2+}$ channels, is blocked by morphine (Michaelson et al., 1984a, b). This block is reversed by naloxone (Michaelson et al., 1984a, b). Although subjected to rather harsh conditions during the purification procedures, synaptosomes have the advantage of being selective for presynaptic effects. Katayama and Nishi (1984) demonstrated that in the mammalian ciliary ganglion, enkephalin elicits both presynaptic inhibition and an increase in $\mathrm{K}^{+}$conductance on ganglion neurons. Margiotta and Berg (1986) found that in cultures of avian ciliary ganglion, enkephalin decreased both the $\mathrm{Ca}^{2+}$ component of the action potential recorded at the soma and the EPSP amplitude between neurons.

There are several difficulties, however, in assuming that the ionic mechanisms of transmitter release and its modulation by opiates or peptides in intact nerve terminals are the same as those found in homogenized cell preparations, neuronal somas, or cultures of neurons (see review by Miller, 1987). Although $\mathrm{N}$-type $\mathrm{Ca}^{2+}$ channels appear to mediate norepinephrine (NA) release in cultured sympathetic neurons (Hirning et al., 1988), the voltage-sensitive $\mathrm{Ca}^{2+}$ channels at intact terminals are as yet uncharacterized. Preparations of isolated intact terminals on the striated muscle iris and on the choroid smooth muscle (Meriney and Pilar, 1987) have the advantage of a homogeneous population of functional cholinergic terminals separate from the neuronal soma. Any effects on ACh release observed in these preparations necessarily imply presynaptic modulation restricted to terminals or processes. Since these 2 targets (iris striated muscle and choroid smooth muscle layer) are anatomically distinct, the physiology of release from these terminals can be easily compared.

The ability to distinguish between characteristics of transmitter release of these 2 preparations of synaptic terminals is also useful in light of recent observations of $\mathrm{ACh}$ release from cultured ciliary ganglion neurons. We have demonstrated that morphine blocks approximately $50 \%$ of $\mathrm{K}^{+}$-evoked ${ }^{3} \mathrm{H}$-acetylcholine ( $\left.{ }^{3} \mathrm{H}-\mathrm{ACh}\right)$ release from cocultures of ciliary ganglion 
neurons and striated muscle (Gray, 1986). Since these cultures contain both populations of cholinergic neurons of the intact ganglion (ciliary and choroid neurons), morphine's 50\% inhibition of transmitter release in coculture may be due either to complete inhibition of release in one population or to partial inhibition in both. Indeed, preliminary experiments on the hatchling iris suggests that $\mathrm{ACh}$ release from ciliary neuron terminals is not sensitive to morphine (Gray et al., 1986). This paper is concerned primarily with the mechanisms by which morphine acts at choroid terminals, since in our studies presynaptic modulation is observed only in the choroid as opposed to the iris. In addition, we have also investigated the effects of several peptides that may be possible candidates for a physiologically relevant role in modulating transmission in these junctions. Among these are several opioids, substance $P$, vasoactive intestinal peptide (VIP), and somatostatin (SS).

The choroid preparation, with its homogeneous cholinergic population of nerve endings, is easily accessible for extensive pharmacological manipulation. In general, peptide receptor-associated effects on synaptic transmission have been thought to be mediated by second messengers such as phospholipid metabolites or cyclic nucleotides (Gilman, 1984; Sekar and Hokin, 1986; Dolphin, 1987; Dunlap et al., 1987; Litosch, 1987; Rane et al., 1987; Worley et al., 1987; Miller, 1988). Recently, many of these effects have been shown to involve GTP binding proteins. We have included in this report a brief survey of the sensitivity of modulation of transmitter release in the choroid to pharmacological agents that alter these second-messenger pathways.

This paper demonstrates that extrinsic regulation of presynaptic ACh release differs markedly between terminals in striated muscle and those in smooth muscle, and describes the events at the molecular level associated with this regulation, indicating that different peptides act through a $G$ protein in the choroid coat. The first part of this study characterizes the biochemistry of the $\mathrm{K}^{+}$-evoked release of ${ }^{3} \mathrm{H}$-ACh from the choroid terminals and its sensitivity to modulatory agents. In the second part, we demonstrate that the neuromodulatory step occurs at the level of voltage-sensitive influx of $\mathrm{Ca}^{2+}$, and we show the role of $\mathrm{G}$ proteins and the lack of effects of second messengers such as cAMP or protein kinase C. These results appear elsewhere in abstract form (Gray and Pilar, 1987).

\section{Materials and Methods}

\section{Choroid and iris preparations}

Tissues were isolated from White Leghorn chickens (2-7 d posthatching), which were killed by decapitation. Eyes were quickly removed from the heads and placed in cold oxygenated Tyrodes $(134 \mathrm{~mm} \mathrm{NaCl}$, $3 \mathrm{mM} \mathrm{KCl}, 20.5 \mathrm{mM} \mathrm{Na}_{2} \mathrm{HCO}_{3}, 3 \mathrm{mM} \mathrm{CaCl}, 1 \mathrm{mM} \mathrm{MgCl}_{2}$, glucosc, 2.2 $\mathrm{g} /$ /iter). For the choroid preparation, a triangular wedge, bordered by the ciliary body, the ciliary nerves, and the optic nerve stump, was cut from the rear of the eyeball. Under the dissecting microscope, the retinal layer was removed with fine forceps. The pigmented epithelium was peeled off with the retina as well. We then freed the vascular choroid layer from the sclera, taking care to cut the proximal ends of the choroid nerve before removing the muscular sheet. This tissue was washed and stored in oxygenated Tyrodes until all choroids were excised. Irises were removed using the procedure described for the choroid, except that the entire iris was dissected out according to previously published protocols (Vaca and Pilar, 1979).

For the denervation experiments, chicks at $1 \mathrm{~d}$ posthatch were anesthetized with methoxyfluorane (Pittman-Moore). An incision was made along the postcrior border of the right cyc socket, and the cye was moved aside to expose the ciliary ganglion. The ganglion was excised, ensuring a complete severing of all the choroid nerve branches. Oxycel was placed in the operated area and the incision was closed. The same procedure, but without the ganglion excision, was conducted for the sham-operated controls. All birds recovered within minutes of the procedure, and the efficacy of the operation could be ascertained by observing pupillary dilation, since the ciliary nerve was cut when the ciliary ganglion was removed.

\section{Incubation conditions}

In the iris at hatching, there is high-affinity $\mathrm{Na}^{\prime}$-dependent choline (Ch) uptake-mediated ACh synthesis (Vaca and Pilar, 1979). To determine whether choroid terminals accumulate $\mathrm{Ch}$ by similar mechanisms, $\mathrm{Ch}$ uptake was measured by incubating excised tissues in normal or $0 \mathrm{Na}^{+}$ Tyrodes $\left(\mathrm{Na}^{+}\right.$replaced by $\left.\mathrm{LiCl}\right)$ Tyrodes containing ${ }^{3} \mathrm{H}-\mathrm{Ch}$ (final specific activity, $8.1 \mathrm{Ci} / \mathrm{mol}$; total choline concentration, $1 \mu \mathrm{M}$ ) and $0.5 \% \mathrm{BSA}$ for $8 \mathrm{~min}$ at $37^{\circ} \mathrm{C}$. This was accomplished by placing tissues in $0.45 \mathrm{ml}$ of loading solution in a $0.5 \mathrm{ml}$ microcentrifuge tube and oxygenating it through a 27 gauge needle. Between 3-6 choroids were placed in each tube and kept in a water bath at $37^{\circ} \mathrm{C}$. After loading, the tissues were spun down for $5 \mathrm{sec}$ at $500 \mathrm{rpm}$ in a Savant tabletop centrifuge. The supernate was withdrawn and discarded unless a wash profile was desired. The tissues at the bottom of the tube were resuspended in $200 \mu \mathrm{l}$ of $0 \mathrm{Ca}^{2+}$ Tyrodes. This wash procedure was repeated 3 times, after which tissues were homogenized in $20 \mu \mathrm{l}$ of formic acid and acetone $(15 / 85, \mathrm{vol} / \mathrm{vol})$ solution with a glass micromortar and pestle on ice. Aliquots, $50 \mu \mathrm{l}$, were dried in scintillation vials and then counted. To measure ACh synthesis rates, incubation solutions also contained $5 \times$ $10^{-4} \mathrm{M}$ eserine sulfate to prevent hydrolysis of $\mathrm{ACh}$. Aliquots of the resulting homogenates were assayed for $\mathrm{ACh}$ as described below. To measure ${ }^{3} \mathrm{H}$-ACh release, tissues were treated as described above with the following exceptions. Incubation with labeled $\mathrm{Ch}$ was extended to $1 \mathrm{hr}$, and $0 \mathrm{Ca}^{2+}$ washes were repeated 7-10 times in $0 \mathrm{Ca}^{2+}$ Tyrodes at room temperature for $30 \mathrm{~min}$ and 3 times in normal Tyrodes at $37^{\circ} \mathrm{C}$. This wash procedure allowed the release of labeled $\mathrm{Ch}$ to decline to baseline levels. Prestimulation release of ${ }^{3} \mathrm{H}$-ACh was measured in 5 min collection periods during preincubation in normal Tyrodes at $37^{\circ} \mathrm{C}$. To evoke release from terminals in the iris and choroid, the tissues were incubated in Tyrodes containing $55 \mathrm{~mm} \mathrm{KCl}$ (equimolar substitution for $\mathrm{NaCl}$ ) for time periods as indicated in the text.

All release solutions, either normal, $0 \mathrm{Ca}^{2+}$, or high-K $\mathrm{K}^{+}$Tyrodes, contained BSA to prevent adhesion of tissues to sides of tubes or bubbler needles and $100 \mu \mathrm{M}$ eserine sulfate to inhibit any endogenous cholinesterases present.

\section{Assay of labeled ACh from homogenates and superfusates}

${ }^{3} \mathrm{H}$-ACh was separated from ${ }^{3} \mathrm{H}-\mathrm{Ch}$ by high-voltage paper electrophoresis and measured by scintillation counting as described previously (Vaca and Pilar, 1979). Then, $120 \mu$ l of supernate was applied to Whatman 3 chromatography paper (Whatman International, Maidstone, England) and dried (in two $60 \mu \mathrm{l}$ steps). The samples were electrophoresed at $50 \mathrm{~V} / \mathrm{cm}$ for $1 \mathrm{hr}$ using the Savant FP $22 \mathrm{~b}$ system with a $1.5 \mathrm{M}$ acetate, $0.75 \mathrm{M}$ formate buffer at $\mathrm{pH} 2$ (Potter and Murphy, 1967). Ch and $\mathrm{ACh}$ had electrophoretic mobilities of 30 and $26 \mathrm{~cm} / \mathrm{hr}$, respectively, with less than $2 \%$ cross-contamination. The compounds were visualized with iodine vapor, and the $\mathrm{ACh}$ spot was cut out and eluted into a scintillation vial with $50 \mu \mathrm{M} \mathrm{HCl}$ in methanol. The elutants were allowed to dry in the vials and were reconstituted with $1 \mathrm{ml}$ of methanol and $10 \mathrm{ml}$ of toluene-based liquid scintillation cocktail (Scintiverse II, Fisher Scientific) and then counted. Recovery was estimated on randomly selected samples where ${ }^{14} \mathrm{C}$ - $\mathrm{ACh}$ was added to the original supernate and compared with final values. Routinely, $50 \%$ of ${ }^{14} \mathrm{C}-\mathrm{ACh}$ was recovered. The following $\mathrm{Ch}$ metabolites were tested for possible contamination in the above assay: $\mathrm{Ch}$, phosphocholine, betaine, and butyrylcholine. No significant migratory overlap of these metabolites could be demonstrated.

Statistical analyses were performed using a 2-tailed Student's $t$ test.

\section{Immunological staining of choroid tissues}

Neuron-specific antibody. A triangular wedge of tissue similar to that used for the ACh release experiments was dissected free in oxygenated $0 \mathrm{Ca}^{2+}$ Tyrodes solution. After removing the retina, any remaining pigment epithelium was removed from the tissue with a small cotton bud, and the choroid muscle was carefully dissected free from the sclera and pinned flat in a Sylgard-coated dish. The tissue was fixed for $10 \mathrm{sec}$ in ice-cold acetone and washed 3 times, 30 min each, in phosphate buffer with $0.3 \%$ Triton X-100 (PBT) before incubation in a monoclonal antibody, C2 (provided by L. T. Landmesser, University of Connecticut), 
diluted $1: 10$ in BSA/PB, for $1 \mathrm{hr}$ at room temperature. This antibody binds to an undefined neuronal cytoskeletal protein and stains the entire axon (Yamamoto et al., 1986; Dahm and Landmesser, 1988). The choroids were washed 3 times in PBT, 30 min each time, and postfixed for $10 \mathrm{~min}$ in cold $4 \%$ paraformaldehyde in $\mathrm{PB}$ ( $\mathrm{pH} 7.3$ ). Following another wash in PBT, the choroids were incubated with goat anti-mouse IgG conjugated to tetramethylrhodamine isothiocyanate (TRITC; Sigmia) at $1: 50$ in $2 \%$ BSA in PBT for 30 min at room temperature, then washed again in 3 changes of $P B$ for 30 min each time and mounted flat between 2 coverslips in Fluoromount G (Fisher Scientific, Orangeburg, NY).

Antibodies against peptides. The choroid, dissected as above, was immediately fixed for $1 \mathrm{hr}$ in cold $4 \%$ paraformaldehyde in $\mathrm{PB}$, then washed overnight at $4^{\circ} \mathrm{C}$ in several changes of PBT. The tissue was incubated in BSA/PBT for $2 \mathrm{hr}$ at room temperature, drained, and then stained by indirect immunohistochemistry for somatostatin-like immunoreactivity (SSLI). Choroids were incubated in rabbit anti-SS antiserum (Axxell, distributed by Accurate Scientific, Westbury, NY) for $24-48 \mathrm{hr}$ at $4^{\circ} \mathrm{C}$. This polyclonal antibody was raised against synthetic cyclic SS 1-14 conjugated to bovine thyroglobulin, but it cross-reacts with synthetic cyclic SS 14-28. The antiserum was diluted 1:500 in $\mathrm{BSA} / \mathrm{PBT}$ and filtered through a $0.2 \mu \mathrm{m}$ filter before use. After incubation in primary antiserum, the choroids were washed in 3 changes of PBT for $1 \mathrm{hr}$ each time and incubated in goat anti-rabbit IgG conjugated to fluorescein isothiocyanate (FITC) at a dilution of 1:50 in BSA/PBT for $1 \mathrm{hr}$ at room temperature. The tissue was washed in 3 changes of PB for $1 \mathrm{hr}$ each time, then removed from the dish and flattened and mounted between 2 glass coverslips in Fluoromount G. Antibody specificity was tested by replacing the primary antiserum with preadsorbed antiserum at the same dilution containing $50 \mu \mathrm{g} / \mathrm{ml}$ synthetic cyclic SS 14-28 or with nonimmune rabbit serum. None of these controls showed staining in the nerve fibers. Antiserum to SS obtained from Axxell was characterized by dot blots, in which synthetic SS 1-14 or SS 14-28 at $1 \mathrm{mM}, 1 \mu \mathrm{M}$, and $1 \mathrm{nM}$ were dried onto nitrocellulose paper and washed in $\mathrm{BSA} / \mathrm{PB}$ overnight at $4^{\circ} \mathrm{C}$, then incubated for $24 \mathrm{hr}$ with anti-SS at 1:500. Following another wash with BSA/PB, the blots were labeled with goat anti-rabbit alkaline phosphatase at 1:2000 and then reacted with the substrate solution. The dot blot analysis demonstrated that the polyclonal antiserum obtained from Axxell stained selectively for SS. This antiserum was the most specific of those available to us. (We wish to thank Dr. Garcia Arraras from the University of Puerto Rico for sending us different antisera to SS for testing.) A similar protocol was used to test for dynorphin immunoreactivity using polyclonal antiserum from Peninsula Labs (Belmont, CA). Similar techniques were also used with irises.

\section{Materials}

${ }^{3} \mathrm{H}-\mathrm{ACh}$ and ${ }^{3} \mathrm{H}-\mathrm{Ch}$ were obtained from New England Nuclear (Boston). The following drugs and reagents were purchased from Sigma Chemical Co. (St. Louis): A23187, BSA, D-Ala- $d$-leu-enkephalin (DADLE), (DAla- $N$-met-phe,gly-ol)-enkephalin (DAGO), dynorphin A, diacylglycerol (DAG), $\beta$-endorphin, eserine sulfate, dibutyryl cAMP, forskolin, dimethyl sulfoxide(DMSO), $\beta$-neo-endorphin, met-enkephalin-arg-phe (MEAP), naloxone (NAL), nifedipine, substance $P$, tetra-deconoyl phorbol acetate (TPA), somatostatin (SS) 14-28, VIP, pertussis toxin (PTX), $4 \alpha$-phorbol 12,13 didecanoate. The following lipid-soluble substances were dissolved in 100\% DMSO stock solutions, and the final DMSO concentrations of the incubation solution was $0.1 \%$ : DAG, TPA, $\alpha \mathrm{PE}$, forskolin, nifedipine, A23187.

\section{Results}

\section{Characterization of Ch uptake and ACh synthesis in choroid terminals}

Previous studies have described the ability of ciliary neuron terminals on the isolated chick iris to take up $\mathrm{Ch}$ through a $\mathrm{Na}^{+}-$ dependent high-affinity carrier-mediated mechanism, synthesize $\mathrm{ACh}$, release $\mathrm{ACh}$ after electrical or high-K ${ }^{+}$stimulation, and increase the rate of $\mathrm{ACh}$ synthesis to compensate for depletion of transmitter stores (Vaca and Pilar, 1979; Pilar et al., 1982). However, no similar studies have been performed on choroid ncuron terminals of the chick eye. Furthermore, it is important to understand the characteristics of cholinergic me-

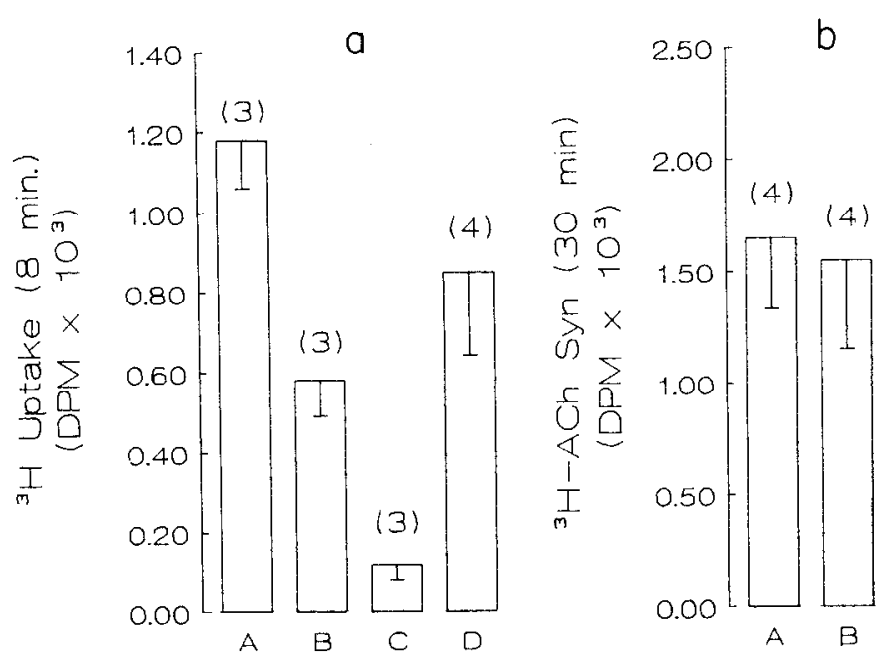

Figure 1. High-affinity $\mathrm{Ch}$ uptake and $\mathrm{ACh}$ synthesis in the avian choroid. $a$, Uptake of ${ }^{3} \mathrm{H}-\mathrm{Ch}$ into choroid wedges was measured with and without $5 \mu \mathrm{M}$ hemicholinium and $0 \mathrm{Na}^{+}$Tyrodes. $A$, Total uptake of ${ }^{3} \mathrm{H}$-Ch per choroid over a $8 \mathrm{~min}$ incubation period in normal Tyrodes containing $1 \mu \mathrm{M}$ Ch ( ${ }^{3} \mathrm{H}-\mathrm{Ch}$ specific activity, $8.3 \mathrm{Ci} / \mathrm{mol}$ ). $B$, Uptake in the $0 \mathrm{Na}^{+}$Tyrodes. $C$, Uptake in normal Tyrodes in the presence of 5 $\mu \mathrm{M}$ hemicholinium. $D$, Uptake in normal Tyrodes following a $10 \mathrm{~min}$ preincubation in high- $\mathrm{K}^{+}(55 \mathrm{~mm})$ Tyrodes. $b$, Synthesis of ${ }^{3} \mathrm{H}-\mathrm{ACh}$ in choroid wedges was measured after incubation for $30 \mathrm{~min}$ in the same solution as in $a$, with the addition of $5 \times 10^{-4} \mathrm{M}$ eserine sulfate. Control synthesis $(A)$ and synthesis following 10 min preincubation in high- $\mathrm{K}^{+}$ Tyrodes $(B)$ are shown. For this figure, and Figures $3 a$ and 4 , values represent means, vertical lines indicate SE, and number in brackets represents number of experiments.

tabolism in these terminals before a comparison between $\mathrm{ACh}$ release in the iris and that in the choroid can be made.

In cholinergic neurons the high-affinity Ch uptake system can be characterized by the following: (1) It operates at micromolar Ch concentrations with a $K_{m}$ of $0.5-2 \mu \mathrm{M}$; (2) it depends on a $\mathrm{Na}^{+}$gradient and is selective for $\mathrm{Na}^{+}$over other monovalent cations (such as $\mathrm{Li}^{+}$); and (3) it is sensitive to hemicholinium, a selective antagonist in the micromolar range. Although there are other criteria for this uptake system, these are reliable indicators of its presence (Pilar et al., 1978).

As shown in Figure $1 a,{ }^{3} \mathrm{H}-\mathrm{Ch}$ uptake in the choroid $(A)$ decreased by $55 \%$ in $0 \mathrm{Na}^{+}$(replaced by an equimolar concentration of $\mathrm{LiCl}$ ) incubation solution, and $(B)$ by over $85 \%$ in 10 $\mu \mathrm{M}$ hemicholinium $(C)$. This difference in inhibition between 0 $\mathrm{Na}^{+}$and hemicholinium was also reported in the myenteric plexus (Pert and Snyder, 1974) and may be due to some inhibition of low-affinity, $\mathrm{Na}^{+}$-independent $\mathrm{Ch}$ uptake that may also contribute to $\mathrm{ACh}$ synthesis. ${ }^{3} \mathrm{H}-\mathrm{ACh}$ accounts for approximately $20-30 \%$ of labeled $\mathrm{Ch}$ taken up via a $\mathrm{Na}^{+}$-dependent mechanism in the choroid. These values are similar to those reported for the avian iris (Vaca, 1980) and for the myenteric plexus (Pert and Snyder, 1974).

Contrary to its effects in the iris preparation, preincubation of choroid terminals for $10 \mathrm{~min}$ in $55 \mathrm{~mm} \mathrm{KCl}$ was not followed by a compensatory increase in either ${ }^{3} \mathrm{H}$-ACh uptake (Fig. $1 a$, $D$ ) or ${ }^{3} \mathrm{H}$-ACh synthesis (Fig. $1 b, B$ ) over controls (Fig. $1 b, A$ ) (Vaca and Pilar, 1979). Increased rates of ACh synthesis in the posthatch chick iris following $\mathrm{K}^{+}$-evoked release are thought to be due to a metabolic coupling to a high-affinity Ch-uptake mechanism (which is also enhanced by $\mathrm{K}^{+}$-cvokcd release) (Suszkiw and Pilar, 1976). This metabolic coupling has been 


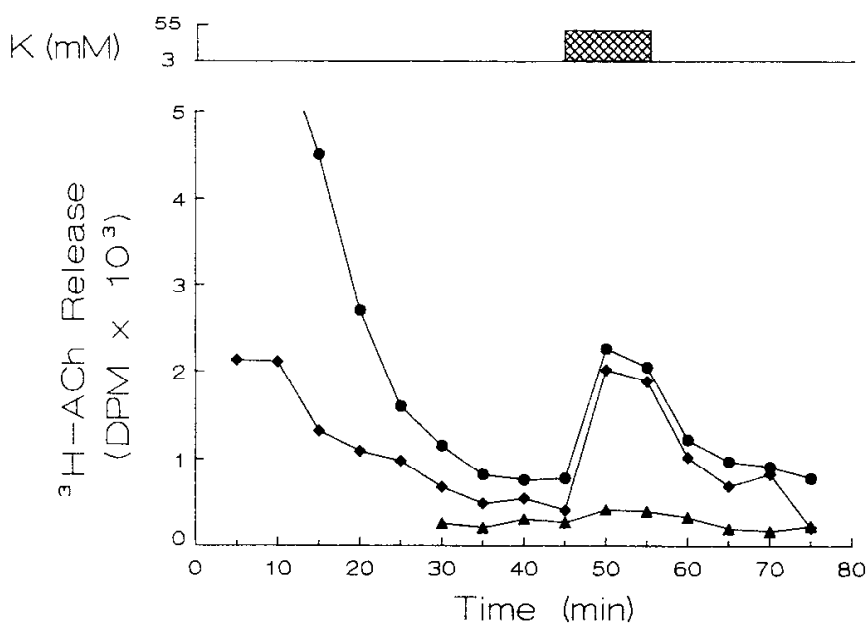

Figure 2. Washout of exogenous ${ }^{3} \mathrm{H}-\mathrm{Ch}$ and evoked release of ${ }^{3} \mathrm{H}-\mathrm{ACh}$ from the choroid coat. Choroidal wedges were incubated in oxygenated avian Tyrodes ( 3 wedges/microcentrifuge tubes) for $70 \mathrm{~min}$ in ${ }^{3} \mathrm{H}-\mathrm{Ch}$ $(1 \mu \mathrm{M} \mathrm{Ch}$; spec. act., $8.3 \mathrm{Ci} / \mathrm{mol})$. At the end of the incubation period, supernates were collected and aliquoted for total or ${ }^{3} \mathrm{H}-\mathrm{ACh}$ counts (see Materials and Mcthods). ACh release was evoked by resuspension and incubation of tissues in $55 \mathrm{~mm} \mathrm{KCl}$ Tyrodes. Cross-hatched areas at the top of the figure indicate the time of exposure to $55 \mathrm{~mm} \mathrm{~K} \mathrm{~K}^{+}$(same in Fig. 3a). Filled circles, total counts in supernate; diamonds, ${ }^{3} \mathrm{H}-\mathrm{ACh}$ counts; triangles, release of ${ }^{3} \mathrm{H}-\mathrm{ACh}$ in $0 \mathrm{Ca}^{2+}$ throughout the wash and the high- $\mathrm{K}^{+}$challenge.

hypothesized to prevent fatigue of synaptic transmission in the posthatch iris (Pilar et al., 1981). The results in the choroid preparation clearly differ from those in the iris; in the choroid there is no depolarization-induced acceleration (even in birds as old as 8 wccks) in ACh synthesis or Ch uptake.

\section{$A C h$ release from choroid terminals}

ACh synthesized from ${ }^{3} \mathrm{H}-\mathrm{Ch}$ uptake was released from choroid tissues during both incubation in normal Tyrodes and stimulation in high- $\mathrm{K}^{+}$Tyrodes. Figure 2 is a graph of a typical experiment showing supernate levels of total ${ }^{3} \mathrm{H}$ (filled circles), release of ${ }^{3} \mathrm{H}-\mathrm{ACh}$ (diamonds), and release of ${ }^{3} \mathrm{H}-\mathrm{ACh}$ in $0 \mathrm{Ca}^{2+}$ Tyrodes throughout the experiment (triangles). During the first 35 min after loading, the decline in total ${ }^{3} \mathrm{H}$ counts represents washout of label primarily from extracellular spaces. Prestimulation release of ${ }^{3} \mathrm{H}$-ACh was measured in 5 min collection periods during incubation in normal Tyrodes just prior to the addition of $\mathrm{K}^{+}$(indicated by the upper cross-hatched bar). To evoke release, tissues were incubated in Tyrodes containing 55 $\mathrm{mm} \mathrm{KCl}$ for two 5 min periods. As can be seen in Figure 2 (diamonds), ${ }^{3} \mathrm{H}-\mathrm{ACh}$ release increased 4 -fold during high- $\mathrm{K}^{+}$ exposure. A large fraction of the evoked release of ${ }^{3} \mathrm{H}-\mathrm{ACh}$ was in the form of ${ }^{3} \mathrm{H}$-ACh. To calculate the percentage of evoked release of ${ }^{3} \mathrm{H}$ due to ${ }^{3} \mathrm{H}-\mathrm{ACh}$, the total amount of ${ }^{3} \mathrm{H}$ or ${ }^{3} \mathrm{H}-\mathrm{ACh}$ was determined during a 10 min high-K+ Tyrodes incubation. Baseline values were subtracted from the evoked values. ${ }^{3} \mathrm{H}$ ACh-evoked release accounted for approximately $90 \%$ of total ${ }^{3} \mathrm{II}$ release. The $\mathrm{K}^{+}$-evoked release in $10 \mathrm{~min}$ represents $26.5 \%$ $(n=3)$ of total labeled ACh.

The $\mathrm{Ca}^{2+}$-dependence of ${ }^{3} \mathrm{H}-\mathrm{ACh}$ release was demonstrated by blocking the $\mathrm{K}^{+}$-evoked release in $0 \mathrm{Ca}^{2+}$ Tyrodes (Fig. 2, triangles). To identify the voltage-sensitive $\mathrm{Ca}^{2+}$ channels mediating $\mathrm{ACh}$ release from choroid terminals, we used nifedipine, a dihydropyridine antagonist. Of the different $\mathrm{Ca}^{2+}$ channels that have been described (Miller, 1987), $N$ and L channels have been implicated in neurosecretion (Takahashi and Ogura, 1983; Enyeart et al., 1985; Turner and Goldin, 1985; Suszkiw et al.,1986; Rane et al., 1987; Hirning et al., 1988). Dihydropyridines (DHPs) have been used to distinguish L channels (Miller, 1987). Therefore, nifedipine, a selective DHP antagonist, would be expected to block $\mathrm{Ca}^{2+}$ current through L channels. Preincubation of choroid tissue with $10 \mu \mathrm{M}$ nifedipine, however, had no significant effect on basal or evoked $\mathrm{ACh}$ release compared with controls (data not shown). Preincubation periods ranging from 10 to 30 min were used to assure the complete drug effect. Preincubation periods of longer than $30 \mathrm{~min}$ were avoided because there is evidence that nifedipine and related antagonists may diffuse intracellularly and modify normal cytoplasmic $\mathrm{Ca}^{2+}$ (Pang and Sperelakis, 1983a, b). In some experiments, nifedipine at the same concentration was administered during a $5 \mathrm{~min}$ preincubation period in $25 \mathrm{mM} \mathrm{K}^{+}$and $0 \mathrm{Ca}^{2+}$ Tyrodes to allow enhanced DHP binding at depolarized potentials (see Sanguinetti and Kass, 1984) prior to the evoked release. In all experiments, nifedipine had no significant effect on ACh release (not shown).

Figure $3 a$ demonstrates that the evoked release of ${ }^{3} \mathrm{H}-\mathrm{ACh}$ originates within the cholinergic terminals of the choroid neurons. The $\mathrm{K}^{+}$-evoked release of ${ }^{3} \mathrm{H}$-ACh in controls (filled circles) completely disappeared after the choroids had been denervated in vivo for $3 \mathrm{~d}$ (open circles). The low level of residual $\mathrm{ACh}$ release after denervation may result from nonsynaptic structures in other nerves or presynaptic debris remaining in the choroid layer. This postdenervation period was chosen because it coincides with the almost complete disappearance of cholinergic fibers and terminals in the choroid layer as measured by immunocytochemical staining. In Figure $3 b$, staining the choroid muscle with a neuron-specific antibody revealed many small nerve fibers throughout the tissue as well as larger fasciculated nerve bundles. Three days after denervation (Fig. 3c), the density of staining decreased dramatically such that only 1 or 2 small nerves could be located after searching the entire preparation. These results support the conclusion that the neuromodulators discussed below influence choroid neuron terminals and that the effects on evoked release are not contaminated by release of label from other neuronal structures in the choroidal layer (Meriney and Pilar, 1987).

\section{Morphine effects on ${ }^{3} \mathrm{H}-\mathrm{ACh}$ release from ciliary ganglion terminals in the iris and the choroid}

The experiments just described form a foundation for investigating the mechanism underlying the modulation of $\mathrm{ACh}$ release by morphine and peptides. As shown in Figures 2 and $3 a$, exposure for $5 \mathrm{~min}$ to Tyrodes containing $55 \mathrm{~mm} \mathrm{~K} \mathrm{~K}^{+}$resulted in a marked release of ${ }^{3} \mathrm{H}-\mathrm{ACh}$ from the isolated, intact ganglionic terminals in both targets, the iris (Fig. $4 a, B$ ) and the choroid (Fig. $4 b, B ; A$ are controls). Addition of $10 \mu \mathrm{M}$ morphine had no effect on evoked release of ${ }^{3} \mathrm{H}$-ACh from terminals in the chick iris (Fig. $4 a, C$ ), although it did abolish this evoked release from terminals in the choroid (Fig. $4 b, C$ ). Interestingly, in the choroid, morphine's inhibition of evoked ACh release was not reversed by $10 \mu \mathrm{M}$ naloxone (Fig. $4 b, D$ ). Even when NAL levels were 10 -fold more than morphine concentrations of 1 or $10 \mu \mathrm{M}$, there was only weak antagonism of the inhibition of $\mathrm{ACh}$ release (maximum reversal by NAL in 5 experiments was 33\%). In these experiments, morphine was added during the last basal release incubation period, and when NAL was administered, it was applied one to five min prior to addition of the morphine. 

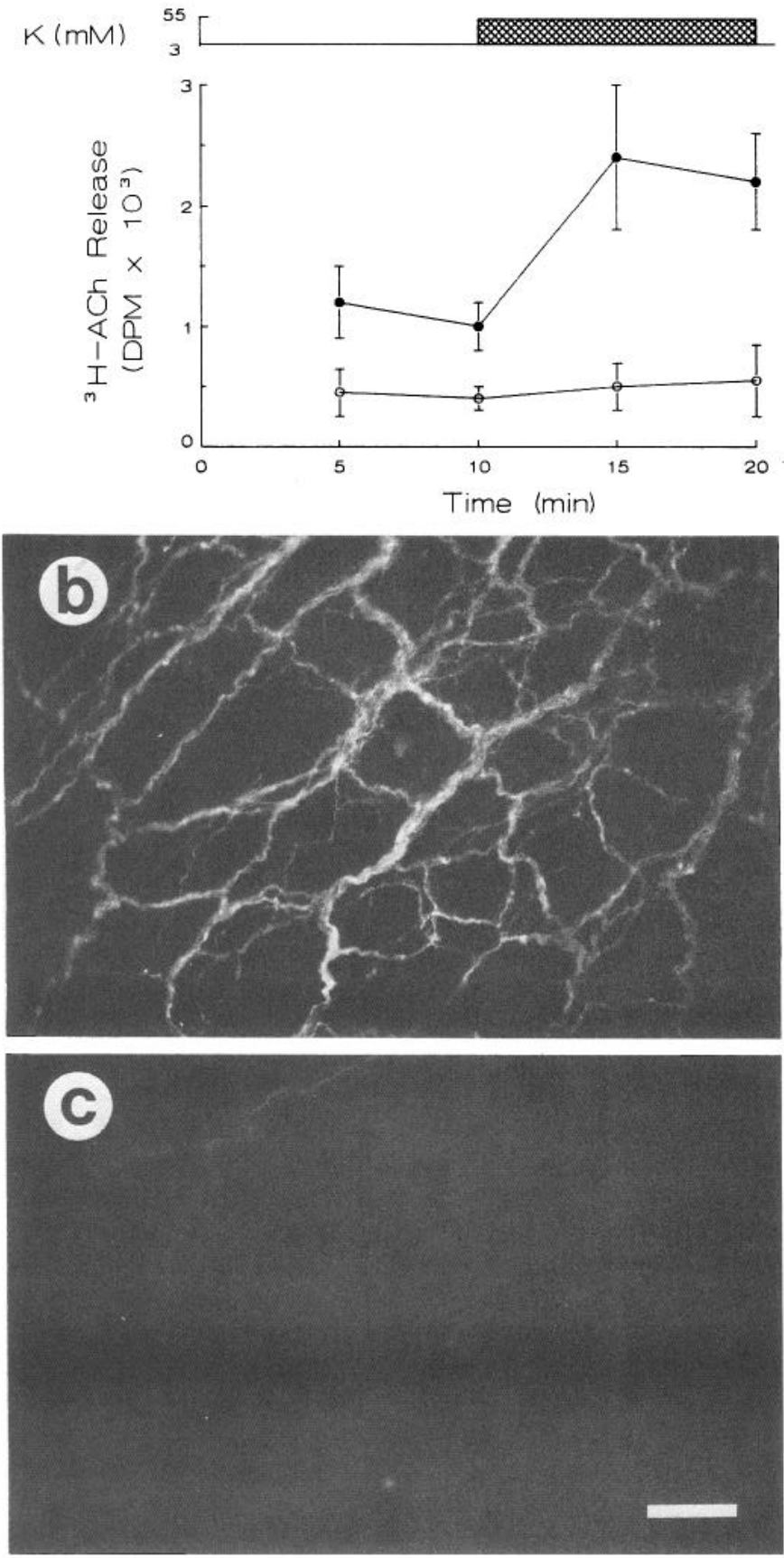

Figure 3. Effect of denervation of choroid nerve on evoked ${ }^{3} \mathrm{H}-\mathrm{ACh}$ release from the choroid and neuron-specific immunoreactivity. $a,{ }^{3} \mathrm{H}$ $\mathrm{ACh}$ release from choroid tissues was measured in $5 \mathrm{~min}$ periods as described earlier in control hatchlings (filled circles) and from choroid tissues denervated $3 \mathrm{~d}$ earlier (open circles). $b$, Photomicrograph of flat, whole-mounted choroid coat stained with a monoclonal antibody to a neural cytoskeletal protein (C2) (see Materials and Methods). Both large and small nerve fibers can be seen under epifluorescence, forming a dense network of axons. $c$, Photomicrograph of flat whole mounts of choroid coat denervated 3 days earlier and stained with $\mathrm{C} 2$ as in $b$. Bar, $100 \mu \mathrm{M}$.

NAL alone had no significant effect on basal or evoked release of labeled ACh (data not shown).

\section{Effects of peptides on ${ }^{3} \mathrm{H}-\mathrm{ACh}$ release}

Since the presynaptic inhibition of transmitter release by morphine was so dramatic, we examined the effects of various opioids

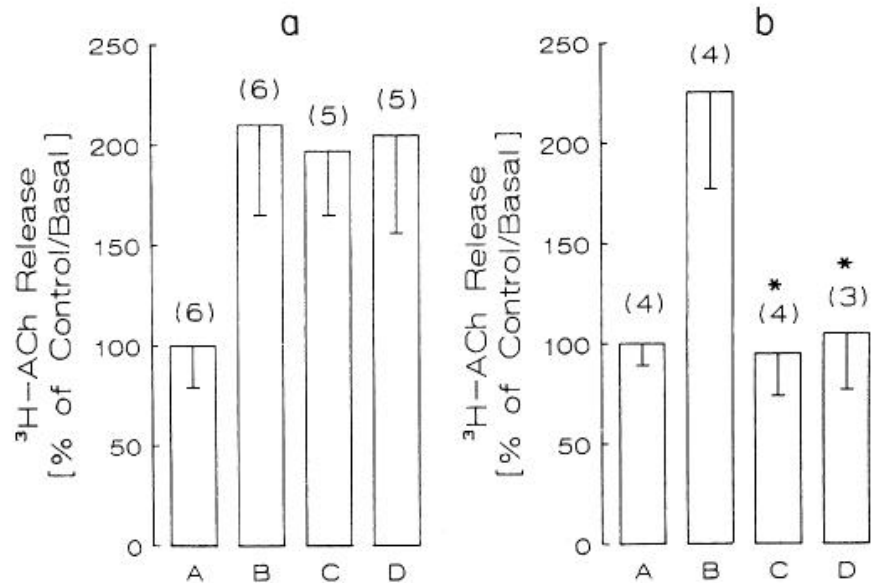

Figure 4. Effect of $10 \mu \mathrm{M}$ morphine sulfate on evoked ${ }^{3} \mathrm{H}-\mathrm{ACh}$ release in the iris $(a)$ and choroid $(b)$. Hatchling irises and choroids were isolated, incubated in ${ }^{3} \mathrm{H}-\mathrm{Ch}$ and analyzed for basal and high- $\mathrm{K}^{+}$-evoked ${ }^{3} \mathrm{H}$-ACh release. Evoked values presented are normalized to the $5 \mathrm{~min}$ basal release period. $A$, Basal release of ${ }^{3} \mathrm{H}-\mathrm{ACh}$ in normal Tyrodes; $B$, ${ }^{3} \mathrm{H}$-ACh release evoked in $55 \mathrm{~mm} \mathrm{KCl}$ Tyrodes for $5 \mathrm{~min} ; C$, $\mathrm{K}^{+}$-evoked release in the presence of $10 \mu \mathrm{M}$ morphine sulfate; $D, \mathrm{~K}^{+}$-evoked release in the presence of both $10 \mu \mathrm{M}$ morphine and $10 \mu \mathrm{M}$ naloxone. Asterisk, significantly different from control evoked release $(B)$ at $p<0.05$ using Student's $t$ test (2-tailed).

and other neuropeptides that may play a role in endogenous regulation of synaptic transmission. These neuropeptides were screened for their ability to modify ${ }^{3} \mathrm{H}-\mathrm{ACh}$ release from choroid terminals (Table 1). Since morphine is an opiate, we tested several well-known opioids (or their derivatives), either endogenous in the chick or known to inhibit transmitter release from autonomic neuronal terminals, such as $d$-alanine, DADLE (a nonhydrolyzable enkephalin analog), neo-endorphin and $\beta$-endorphin (from the proopiomelanocortin precursor), dynorphin (the best-known opioid from the proenkephalin B family), and MEAP [a heptapeptide from the proenkephalin A family that has been shown to inhibit ACh release from sympathetic ganglion (Araujo and Collier, 1987)]. In addition, several other peptides seemed to be likely candidates for a neuromodulatory role in this system: SS (Guillemin, 1976; Tsunoo et al., 1986; Weill, 1987), substance P, and VIP (Lundberg et al., 1980; Nicoll et al., 1980; Lundberg, 1981; Role, 1984; Dryer and Chiappinelli, 1985).

Dynorphin and MEAP both inhibited ${ }^{3} \mathrm{H}-\mathrm{ACh}$ release at micromolar levels. The inhibition by these compounds was only weakly antagonized by $100 \mu \mathrm{M}$ NAL. Interestingly, the most potent peptide tested thus far in the choroid, including the opiates, is SS, which at $100 \mathrm{~nm}$ completely inhibited the evoked release. As was the case with morphine, SS had no significant effect on ${ }^{3} \mathrm{H}-\mathrm{ACh}$ release from ciliary neuron terminals in the intact iris. The control evoked release was $252 \pm 24 \%$ of prestimulation levels. When $100 \mu \mathrm{M}$ SS was added, the evoked release remained unchanged $(274 \pm 41 \%$ of prestimulation release; values are means $\pm \mathrm{SE}, n=3$ ). Substance P, VIP, DADLE, neo-endorphin, and $\beta$-endorphin had no significant effect on labeled release from the choroid even at concentrations of 10 $\mu \mathrm{M}$.

\section{Ionic mechanisms that mediate neuromodulation}

The inhibition of $\mathrm{K}^{+}$-evoked transmitter release may be caused by one of several mechanisms, which involve either increasing 


\section{A 23187}

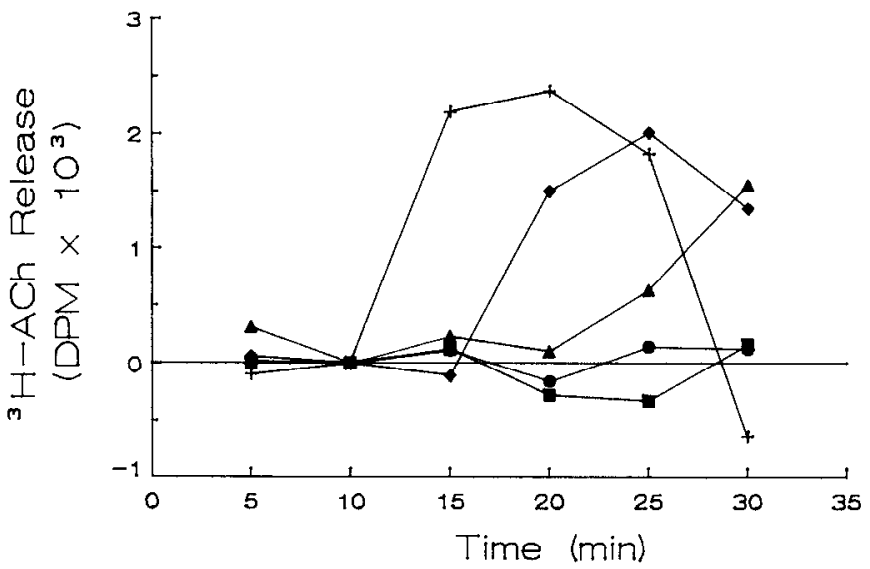

Figure 5. Dose-response analysis of ${ }^{3} \mathrm{H}$-ACh release evoked by the calcium ionophore A23187. ${ }^{3} \mathrm{H}-\mathrm{ACh}$ release from choroid tissues evoked by addition of A23187 measured in 5 min periods as described. Concentrations of A23187 are plotted as follows: filled circles, $0.01 \mu \mathrm{M}$; squares, $0.1 \mu \mathrm{M}$, triangles, $2 \mu \mathrm{M}$; diamonds, $5 \mu \mathrm{M}$; crosses, $10 \mu \mathrm{M}$. For ease in comparing temporal patterns and amplitude of ionophore-induced ${ }^{3} \mathrm{H}$-ACh release, prestimulation values (DPM ${ }^{3} \mathrm{H}-\mathrm{ACh}$ released in the last $5 \mathrm{~min}$ prior to exposure to ionophore) are subtracted from all values. Note that the latency of ${ }^{3} \mathrm{H}$-ACh release decreases with increasing concentrations of ionophore. A23187 was added to incubation solutions in $0.1 \%$ DMSO as indicated in this figure and in Figure 6 by the cross-hatched area at the top.

or decreasing specific ionic conductances on the nerve terminal, thereby decreasing intraterminal $\mathrm{Ca}^{2+}$ levels, or by activating an intraterminal process that interferes with the $\mathrm{Ca}^{2+}$-dependent exocytosis of ACh. To determine which of these mechanisms is responsible for the presynaptic inhibition described above, we tested the effects of SS and morphine on ${ }^{3} \mathrm{H}-\mathrm{ACh}$ release evoked by incubation with a $\mathrm{Ca}^{2+}$ ionophore, A23187. This ionophore increases $\mathrm{Ca}^{2+}$ membrane permeability by creating new nonvoltage-dependent $\mathrm{Ca}^{2+}$ channels.

Figure 5 shows the effect of increasing doses of A23187 on ${ }^{3} \mathrm{H}-\mathrm{ACh}$ release from the choroid. Concentrations of ionophore below $1 \mu \mathrm{M}$ (filled circles and squares) did not elicit release within the $20 \mathrm{~min}$ assay period. At $2 \mu \mathrm{M}$ (triangles), release is evoked, but not until more than $10 \mathrm{~min}$ after exposure to the ionophore, while at concentrations above $5 \mu \mathrm{M}(+)$, evoked release is apparent immediately. This release disappears in $0 \mathrm{Ca}^{2+}$ Tyrodes with $5 \mu \mathrm{M}$ A23187 (not shown). Figure 6 demonstrates that SS does not affect ACh release evoked by either 1 or $10 \mu \mathrm{M}$ A23187. As shown in the previous figurc, the low ionophore concentrations (filled squares $=1 \mu \mathrm{M} \mathrm{A23187)}$ ) evoked a delayed and small ${ }^{3} \mathrm{H}-\mathrm{ACh}$ release over a $20 \mathrm{~min}$ period. Addition of SS (open squares) did not affect the latency or amount of ${ }^{3} \mathrm{H}-\mathrm{ACh}$ release. Incubation with $10 \mu \mathrm{M}$ A23187 (filled circles) caused a marked and immediate increase in ${ }^{3} \mathrm{H}-\mathrm{ACh}$ release, which also was not affected by the addition of SS (open circles). In similar experiments, $10 \mu \mathrm{m}$ morphine also did not affect ionophore-induced release. If peptide neuromodulation occurs at the level of exocytosis or after $\mathrm{Ca}^{2+}$ influx, then SS or morphine should have been able to inhibit the $\mathrm{Ca}^{2+}$ ionophore-induced release, especially at low concentrations of A23187. These results support the hypothesis that inhibition of $\mathrm{ACh}$ release in choroid terminals occurs via a decreased $\mathrm{Ca}^{2+}$ influx rather than by inhi-
Table 1. Peptides and $\mathrm{K}^{+}$-evoked ${ }^{3} \mathrm{H}-\mathrm{ACh}$ release from the chick choroid

\begin{tabular}{lc} 
Substance & $\begin{array}{l}\text { \% Control e } \\
\text { release }\end{array}$ \\
\hline DADLE & \\
$1 \mu \mathrm{M}$ & $89 \pm 19$ \\
$10 \mu \mathrm{M}$ & $82 \pm 24$ \\
Neo-endorphin, $1 \mu \mathrm{M}$ & $110 \pm 8$ \\
$\beta$-Endorphin & \\
$1 \mu \mathrm{M}$ & $142 \pm 49$ \\
$10 \mu \mathrm{M}$ & $108 \pm 31$ \\
Dynorphin & \\
$1 \mu \mathrm{M}$ & $41 \pm 9$ \\
$10 \mu \mathrm{M}$ & $14 \pm 16^{a}$ \\
$10 \mu \mathrm{M}+100 \mu \mathrm{M}$ NAL & $24 \pm 17$ \\
MEAP & \\
$1 \mu \mathrm{M}$ & $71 \pm 11$ \\
$10 \mu \mathrm{M}$ & $15 \pm 23^{a}$ \\
$10 \mu \mathrm{M}+100 \mu \mathrm{M}$ NAL & $4 \pm 34^{a}$ \\
SS, $100 \mathrm{nM}$ & $5 \pm 21^{a}$ \\
Substance P & \\
$1 \mu \mathrm{M}$ & $92 \pm 12$ \\
$10 \mu \mathrm{M}$ & $122 \pm 16$ \\
$\mathrm{VIP}, 1 \mu \mathrm{M}$ & $101 \pm 28$
\end{tabular}

${ }^{3} \mathrm{H}-\mathrm{ACh}$ release from choroid wedges in the presence or absence of various peptides was measured before and during a 5 min incubation in $55 \mathrm{~mm} \mathrm{KCl}$ Tyrodes. Peptides were added to the high- $\mathrm{K}^{+}$incubation period and also to the last basal release period to ensure adequate diffusion. Each value in this table and in Tables 2-4 represents at least 3 experiments normalizing to $100 \%$ of the average $\mathrm{K}^{+}$-evoked release of controls in each experiment. Values are means of percentages \pm SE for Tables $1-4$.

"Significantly different from control evoked release at $p<0.01$

hition of an exocytotic process following $\mathrm{Ca}^{2+}$ entry. Although ionophore-induced $\mathrm{Ca}^{2+}$ entry into the terminal may eventually saturate or overload the regulation of the exocytotic process, the fact that these neuromodulators have no effect at threshold concentrations of ionophore argues against this possibility.

\section{Effects of possible intracellular second messengers}

We have shown above that cholinergic terminals in choroid smooth muscle are sensitive to morphine, dynorphin, and SS. In Table 2, we show that the inhibition of ${ }^{3} \mathrm{H}-\mathrm{ACh}$ release is blocked by preincubation with pertussis toxin (PTX) (200 units/ $\mathrm{ml}$ an hour before collection period), strongly implicating a $\mathrm{G}$ protein-mediated mechanism. Therefore, the modulation of transmitter release at choroid terminals by morphine, SS, and dynorphin is mediated through GTP binding proteins, perhaps $\mathrm{G}_{i}$ or $\mathrm{G}_{\mathrm{o}}$. It is important to emphasize that incubation with PTX alone had no effect on either basal or $\mathrm{K}^{+}$-evoked ${ }^{3} \mathrm{H}$-ACh release in the choroid.

To determine if the presynaptic inhibition described above involves an intracellular messenger between a $G$ protein and an ionic channel, we examined the effects of 2 well-known messengers, cAMP and DAG (an activator of protein kinase C). We observed the effects of direct application of dibutyryl cAMP and forskolin (an activator of adenylate cyclase) on evoked release in the presence and absence of morphine and SS (Table 3). If the actions of these neuromodulators are mediated through a decrease in cAMP [as has been shown to be the case for many modulators that activate $G_{i}$ (Gilman, 1984)], then increasing 


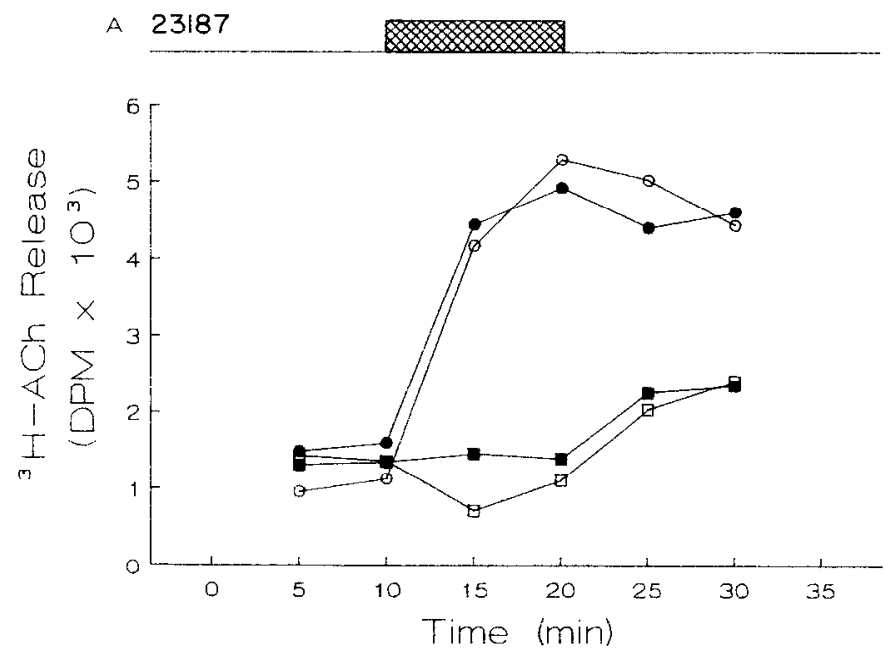

Figure 6. Effect of SS on A23187-evoked ${ }^{3} \mathrm{H}$-ACh release. Controls show ${ }^{3} \mathrm{H}$-ACh release, as described in Figure 5, evoked by $1.0 \mu \mathrm{M}$ (filled squares) and $10 \mu \mathrm{M}$ (filled circles) A23187. The effect of $100 \mathrm{nM}$ SS on the release evoked by $1.0 \mu \mathrm{M}$ (open squares) and $10 \mu \mathrm{M}$ (open circles) A23187 is almost identical to controls in time course and amplitude.

intraterminal cAMP should reverse the inhibitory effects of SS and morphine. Table 3 shows that elevating cAMP levels, either directly with dibutyryl cAMP or indirectly through adenylate cyclase stimulated by forskolin, did not reverse the inhibition of evoked release by morphine or SS. In addition, these compounds had no effect on evoked release in controls.

Another second-messenger pathway we investigated involves the activation of protein kinase $\mathrm{C}$ (PKC) by DAG, which has been shown to affect ion channel opening and transmitter release (Kaczmarek, 1987; Shapira et al., 1987). In addition to DAG, we also investigated TPA (a $\beta$ phorbol ester), which is known to strongly stimulate PKC activity in chick ciliary ganglion (Montz et al., 1985). Table 4 lists the effects of $\beta$ phorbol esters and $\mathrm{DAG}$ on $\mathrm{K}^{+}$-evoked ${ }^{3} \mathrm{H}-\mathrm{ACh}$ release in the presence and absence of morphine and SS. In all the experiments, we found no cffccts of DAG or TPA on prestimulation ${ }^{3} \mathrm{H}-\mathrm{ACh}$ release (data not shown), evoked ${ }^{3} \mathrm{H}-\mathrm{ACh}$ release, or its inhibition. To ensure that phorbol esters had sufficient time for activation of PKC or, alternatively, that the exposure was not prolonged to the point that desensitization occurred, the duration of phorbol ester and DAG incubation was varied from $2 \mathrm{hr}$ to $10 \mathrm{~min}$ with no significant difference in effect. An $\alpha$ phorbol ester, used as a control because it does not activate $\mathrm{PKC}$, had no effect either. The carrier DMSO $(0.1 \%)$ also had no effect on basal or evoked ${ }^{3} \mathrm{H}-\mathrm{ACh}$ release.

Table 2. ${ }^{3} \mathrm{H}-\mathrm{ACh}$ release sensitivity to pertussis toxin

\begin{tabular}{lcc} 
& \multicolumn{2}{c}{ \% Inhibition of evoked release } \\
\cline { 2 - 3 } Condition & Control & PTX \\
\hline Tyrodes & 0 & $2 \pm 16$ \\
Morphine $(10 \mu \mathrm{M})$ & $102 \pm 9$ & $11 \pm 7^{a}$ \\
SS $(100 \mathrm{nM})$ & $95 \pm 22$ & $-8 \pm 21^{a}$ \\
Dynorphin $(10 \mu \mathrm{M})$ & $86 \pm 18$ & $6 \pm 25^{a}$ \\
\hline
\end{tabular}

${ }^{3} \mathrm{H}-\mathrm{ACh}$ release from choroid wedges in the presence or absence of morphine or other peptides after preincubation with pertussis toxin $(200 \mathrm{units} / \mathrm{ml})$ for $1 \mathrm{hr}$.

${ }^{a}$ Significantly different from controls at $p<0.01$.
Table 3. Second messengers and evoked ${ }^{3} \mathrm{H}-\mathrm{SCh}$ release: effects of morphine and SS in the presence of cAMP and forskolin

\begin{tabular}{lccc} 
& \multicolumn{3}{c}{ \% Control evoked release } \\
\cline { 2 - 4 } Condition & Tyrodes & $\begin{array}{l}\text { Dibutyryl } \\
\text { cAMP }\end{array}$ & Forskolin \\
\hline Control & 100 & $65 \pm 46$ & $100 \pm 11$ \\
Morphine $(10 \mu \mathrm{M})$ & $-3 \pm 11$ & $2 \pm 17$ & $8 \pm 9$ \\
SS $(100 \mathrm{nM})$ & $4 \pm 18$ & $5 \pm 22$ & $-12 \pm 16$
\end{tabular}

${ }^{3} \mathrm{H}-\mathrm{ACh}$ release from choroid wedges in the presence or absence of morphine and somatostatin after preincubation with dibutyryl cAMP $(0.1 \mathrm{mM})$ or forskolin $(10$ $\mu \mathrm{M})$ for $20 \mathrm{~min}$. Each value represents the mean of at least 3 experiments normalized to $100 \%$ of either the basal or the $\mathrm{K}^{+}$-evoked controls in each experiment. Same in Table 4.

\section{Characterization and localization of endogenous peptides}

As a first step in assessing whether the inhibition of transmitter release by $S S$ that we demonstrated has any functional relevance, we stained choroid tissue with a polyclonal antiserum to SS. As shown in Figure 7, SSLI was found throughout the mesh of nerve fiber bundles in the choroid. The overall pattern of staining was similar to that revealed with the neuron-specific antibody (Fig. 3b), except that SSLI was weak or absent in the larger fiber bundles. No SSLI or dynorphin staining was observed in irises (not shown).

\section{Discussion}

The results from this study clearly show that ${ }^{3} \mathrm{H}-\mathrm{ACh}$ release is morphine-sensitive in ciliary ganglion terminals in the choroid, but not in the iris. This is similar to observations of target muscle contractile responses after repetitive stimulation of the ciliary ganglion, where morphine decreases the amplitude of the choroid contractions by $40 \%$ but has no effect in the iris (S. D. Meriney and G. R. Pilar, unpublished observations). Furthermore, these results support the hypothesis that the $50 \%$ inhibition of ${ }^{3} \mathrm{H}-\mathrm{ACh}$ release measured in cocultures of neurons with striated muscle may be due to presynaptic opiate receptors present exclusively on the choroid neurons. However, it is not clear from Margiotta and Berg's experiments on cultured ciliary ganglion neurons (1986) if the decrease in $\mathrm{Ca}^{2+}$ current and EPSP amplitude caused by enkephalin was observed in both ciliary and choroid neurons. Thus, it remains possible that in culture both populations of ciliary ganglion neurons possess functional opiate receptors that are unable to fully inhibit ${ }^{3} \mathrm{H}-\mathrm{ACh}$ release. We are planning to test this latter hypothesis in another series of experiments that will involve separation of these populations in vitro.

Table 4. Second messengers and evoked ${ }^{3} \mathrm{H}-\mathrm{ACH}$ release: effects of morphine and SS in the presence of DAG or TPA

\begin{tabular}{lrrr} 
& \multicolumn{3}{c}{$\%$ Control evoked release } \\
\cline { 2 - 4 } & \multicolumn{1}{c}{ Tyrodes } & \multicolumn{1}{c}{ DAG } & \multicolumn{1}{c}{ TPA } \\
\hline Control & \multicolumn{1}{c}{100} & $128 \pm 31$ & $87 \pm 27$ \\
Morphine $(10 \mu \mathrm{M})$ & $11 \pm 17$ & $18 \pm 12$ & $6 \pm 23$ \\
SS $(100 \mathrm{nM})$ & $-8 \pm 21$ & $9 \pm 15$ & $-12 \pm 19$ \\
\hline
\end{tabular}

${ }^{3} \mathrm{H}$-ACh release from choroid wedges in the presence or absence of morphine and somatostatin after preincubation with $1 \mu \mathrm{M}$ TPA (a $\beta$ phorbol ester) for $30 \mathrm{~min}$ and DAG $(10 \mu \mathrm{M})$ for $30 \mathrm{~min}$. 


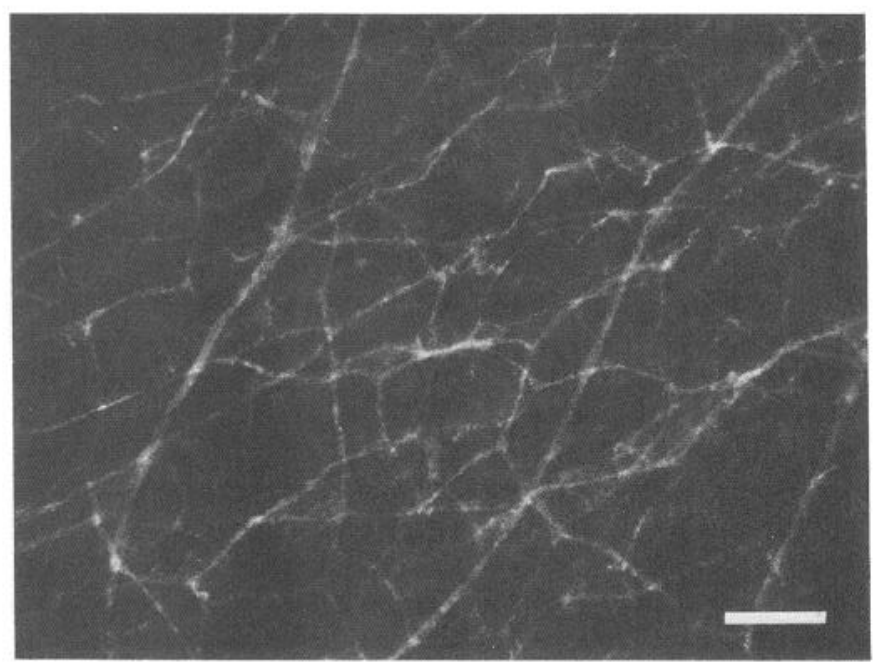

Figure 7. SS immunoreactivity in the choroid. Flat, whole-mounted choroid coat stained with anti-SS $(1: 500)$ antibodies. Note that nerve patterns in Figures $3 b$ and 7 are similar but are from 2 different 3-dold chicks. Scale bar, $100 \mu \mathrm{M}$.

The finding that ${ }^{3} \mathrm{H}-\mathrm{ACh}$ release from terminals in the vascular smooth muscle of the chick choroid is also inhibited by SS and dynorphin and that this inhibition is blocked by pretreatment with PTX suggests that transmitter release in choroid neuromuscular junctions is regulated by presynaptic receptors linked to $\mathrm{G}$ proteins. Although opiates and SS have been shown to modify synaptic transmission in other tissues (reviewed by Paton, 1957; Frederickson and Pinsky, 1971; Bixby and Spitzer, 1983; North, 1986), our experiments suggest that inhibition of $\mathrm{ACh}$ release requires activation of a $\mathrm{G}$ protein-mediated mechanism that eventually decreases $\mathrm{Ca}^{2+}$ influx in nerve terminals. Morphine, SS, and dynorphin all inhibit ${ }^{3} \mathrm{H}-\mathrm{ACh}$ release in avian choroid, and all are blocked by PTX. Neither the effects of morphine nor those of SS are altered by agents that change cyclic nucleotide levels and activate $\mathrm{PKC}$, and no inhibition by any agent is seen with $\mathrm{Ca}^{2+}$ ionophore-induced release. Although a number of G proteins are PTX-sensitive (Dunlap et al., 1987), the similarity between modulator effects argues for a common mechanism affecting voltage-sensitive $\mathrm{Ca}^{2+}$ influx into the nerve terminal. However, since we have no way of directly measuring changes in PKC activity or cyclic nucleotide levels in choroid terminals and we have not investigated all possible cellular messengers, such as $\mathrm{IP}_{3}$ and $\mathrm{Ca}^{2+}$ liberated from intracellular stores, this conclusion must remain speculative.

We were surprised to find that a $\mathrm{G}$ protein-mediated mechanism did not involve changes in either cAMP levels or PKC activity. Although it is quite possible that another second messenger is active in choroid nerve terminals, recent evidence has demonstrated that $\mathrm{G}$ proteins may not need a cytoplasmic molecular intermediate to exert their effects on ion channels. Indeed, several investigators have reported effects of ACh-stimulated $\mathrm{G}$ protein subunits directly on $\mathrm{K}^{+}$conductance in atrial cells (Logothetis et al., 1987; Yatani et al., 1987a, b). In rat sympathetic neurons, muscarinic modulation of $\mathrm{N}$-type $\mathrm{Ca}^{2+}$ channels appears to be mediated by a PTX-sensitive $\mathrm{G}$ protein that is not associated with either cAMP-dependent protein kinase or PKC (Wanke et al., 1987). Hescheler et al. (1988) have also demonstrated enhancement of reconstituted voltage-sensitive $\mathrm{Ca}^{2+}$ currents that is not mediated through cyclic nucleo- tides. Furthermore, in the hippocampus several transmitters (GABA, 5HT, and adenosine) have been shown to increase current through the same $\mathrm{K}^{+}$channel via $\mathrm{G}$ proteins independent of traditional second messengers (Nicoll, 1988). Thus, the apparent lack of effect of forskolin or PKC activators in our system is not unusual and suggests that a $G$ protein or subunit thereof may bind directly to the channel; alternatively, an as yet unknown molecule or molecular cascade may be interposed.

The results discussed above are concerned with pharmacological manipulation of transmitter release in the choroid. An important question that can be asked is whether endogenous peptides regulate transmission in a similar manner. The case for the presence of endogenous opioids in the choroid is not yet convincing. Although the existence of endogenous opioids has been demonstrated in terminals of Edinger-Westphal neurons [which are presynaptic to neurons in the ciliary ganglion (Erichsen et al. 1982; M. J. Ford, E. D. Oliva, and G. R. Pilar, unpublished observations)], neither the identity of the peptides nor the the nature of the opiate receptor in the ganglion is known. Although Erichsen et al. (1981) reported $\delta$ receptors in the pigeon ciliary ganglion, we, in collaboration with Dr. W. Shoemaker (from the University of Connecticut Health Center), have not found $\delta$ receptors in the chick ciliary ganglion; rather, we detected $\kappa$ and low levels of $\mu$ receptors (unpublished observations). In the choroid, however, neither endogenous opioids nor their receptors have been reported. The relatively high concentrations (10 $\mu \mathrm{M}$ level) required for modulatory activity of dynorphin and MEAP, and NAL's apparent inefficacy, suggest that the receptor is not of the classic $\mu, \kappa$, or $\delta$ type. In fact, several recent studies report morphine effects that are not sensitive to naloxone (Bernardi et al., 1986). However, it is also premature to rule out cross-reactivity with the SS receptor. Conversely, it is also possible that there is a broad, diverse array of presynaptic receptors that all work through a common PTX-sensitive G protein, as has been suggested for the secretin family (Marx, 1987).

We have, however, stronger evidence implicating endogenous modulatory activity of SS. First, we have confirmed a previous observation (Epstein and Dahl, 1987) that SS is present in choroid terminals. Second, denervating the choroid layer clearly abolished the evoked release of ${ }^{3} \mathrm{H}-\mathrm{ACh}$ as well as SSLI. This indicates that the release sites being examined are on the terminals and fibers of the cholinergic choroid neurons of the ciliary ganglion. Finally, it is interesting that terminals on the striated chick iris do not show modulation of ACh release with morphine or SS. SSLI is present on choroid fibers and is not on ciliary terminals in the iris. This correlation of localization and physiological effect argues for the existence of endogenous modulation in the choroid terminals, although we still lack direct evidence showing SS release or changes in ACh release after depletion of somatostatin from terminals (Sagar et al., 1982).

\section{Mechanism of presynaptic inhibition}

Presynaptic modulation at choroid terminals appears to involve a $\mathrm{G}$ protein linked to $\mathrm{Ca}^{2+}$ influx. There is, however, other evidence showing that SS and opioids activate $\mathrm{K}^{+}$conductances (Moore et al., 1988), which may lead to presynaptic inhibition (Yamashita et al., 1987). A decreased presynaptic $\mathrm{Ca}^{2+}$ influx caused by opiates or peptides has generally been ascribed to 1 of 2 mechanisms (reviewed by North, 1986): either an increase in $\mathrm{K}^{+}$conductance or a direct inhibition of $\mathrm{Ca}^{2+}$ conductance. In our experiments, inhibition of ${ }^{3} \mathrm{H}$-ACh release by increased 
$\mathrm{K}^{+}$conductance can be ruled out. Since release is evoked by raising external $\mathrm{K}^{+}$levels to $55 \mathrm{~mm}$, which changes its equilibrium potential to approximately $-20 \mathrm{mV}$, an increase in $\mathrm{K}^{+}$ conductance would act to clamp the membrane potential near this value, facilitating release rather than inhibiting it.

Other electrophysiological studies have shown that opiates block voltage-dependent $\mathrm{Ca}^{2+}$ channels in neuroblastoma-glioma cells via a $\mathrm{G}$ protein (Hescheler et al., 1987) and block thc $\mathrm{Ca}^{++}$ component of somal action potentials as well (Mudge et al., 1979). Inhibition of $\mathrm{Ca}^{2+}$ entry by enkephalin has been implicated in cultured ciliary ganglion neurons (Margiotta and Berg, 1986) and demonstrated in whole-cell patch-clamp studies in neuroblastoma-glioma cells (Tsunoo et al., 1986). In these latter studies, SS was shown to be active as well in a similar concentration range (25-100 $\mathrm{nm}$ ) to that reported here. However, technical restrictions have prevented recording from channels in the axon or terminal. Modulation of intracellular events secondary to $\mathrm{Ca}^{2+}$ entry is ruled out in choroid terminals by the lack of modulator effect on $\mathrm{Ca}^{2+}$ ionophore-induced release. Thus, the most likely candidate in our system for modulation of $\mathrm{ACh}$ release is the $\mathrm{Ca}^{2+}$ influx into the terminal.

The nature of opioid receptors that are linked to transmitter release is yet unknown. In the neuroblastoma-glioma hybrids mentioned above, only $\delta$ opiate receptors are present (Tsunoo et al., 1986) and the enkephalin effect is reversible by $1 \mu \mathrm{M}$ NAL. In addition, the $\mathrm{Ca}^{2+}$ current that is inhibited in these cells is noninactivating and thus may not play an important role in transmitter release (Scott and Dolphin, 1987). North and his colleagues (see North, 1986) have suggested a functional dichotomy between opiate receptors that increase $\mathrm{K}^{+}$conductance ( $\mu$ and $\delta$ receptors) and those that decrease $\mathrm{Ca}^{2+}$ conductance $(\kappa)$. Previous receptor studies in the other peripheral target of the ciliary ganglion, the iris (D. B. Gray, T. Devlin, G. R. Pilar, and $W$. Shoemaker, unpublished observations), have identified specific $\kappa$ ligand binding (using ${ }^{125}$ I-ethyl ketacyclazine), but no receptor data for the choroid are available. However, dynorphin, a $k$ agonist, has been shown to selectively inhibit transient, highthreshold $\mathrm{Ca}^{2+}$ currents (characteristic of $\mathrm{N}$-like channels) in cultured mouse dorsal root ganglion cells (Gross and MacDonald, 1987). This observation suggests a possible link between the $\kappa$ receptor and modulation of transmitter release.

Our results leave open to question the precise nature of the voltage-sensitive $\mathrm{Ca}^{2+}$ channels responsible for $\mathrm{K}^{+}$-evoked ${ }^{3} \mathrm{H}$ $\mathrm{ACh}$ release from choroid terminals. Studies in cultured rat sensory and sympathetic neurons (Perney et al., 1986; Holz et al., 1988) show that release of substance $P$ is sensitive to dihydropyridines, whereas release of noradrenaline is completely resistant to this class of $\mathrm{Ca}^{2+}$ channel antagonist, indicating multiple $\mathrm{Ca}^{2+}$ channel types in the regulation of transmitter release. However, in our study, since nifedipine had little effect, even after preincubation in depolarized conditions, it is improbable that L-type channels mediate ACh release; N-like channels do appear to be candidates for this role.

In conclusion, these experiments have used a nonphysiological stimulus, maintained depolarization by raising external $\mathrm{K}^{+}$ concentration, to demonstrate the potential role of SS and opioids in presynaptic neuromodulation. The next step will be to ascertain (1) the efficacy of these neuromodulators on transmitter release evoked by physiological nerve stimulation, and (2) if these neoropeptides are present and released from choroid nerves, and with what frequency of nerve activity they play a physiological role in feedback control of synaptic transmission.

\section{References}

Araujo, D. M., and B. Collier (1987) Effect of endogenous opioid peptides on acetylcholine release from the cat superior cervical ganglion: Selective effect of a heptapeptide. J. Neurosci. 7: 1698-1704.

Bernardi, G., P. Calabresi, N. Mercuri, and P. Stanzione (1986) Action of morphine on rat cortical neurons intracellularly recorded in vivo: Evidence for an excitatory postsynaptic effect which is naloxone insensitive. Neuroscience 18: 31-41.

Bixby, J. L., and N. C. Spitzer (1983) Enkephalin reduces quantal content at the frog neuromuscular junction. Nature 301: 431-432.

Bornstein, J. C., and H. L. Fields (1979) Morphine presynaptically inhibits a ganglionic cholinergic synapse. Neurosci. Lett. 15: 77-82.

Cherubini, E., and R. A. North (1985) $\mu$ and $\kappa$ opioids inhibit transmitter release by different mechanisms. Proc. Natl. Acad. Sci. USA 82: 1860-1863.

Dahm, L. M., and L. T. Landmesser (1988) The regulation of intramuscular nerve branching during normal development and following activity blockade. Dev. Biol. 130: 621-644.

Dolphin, A. C. (1987) Nucleotide binding proteins in signal transduction and disease. Trends Neurosci. 10:53-57.

Dryer, S. E., and V. A. Chiappinelli (1985) Substance P depolarizes nerve terminals in an autonomic ganglion. Brain Res. 336: 190-194.

Dunlap, K., G. G. Holz, and S. G. Rane (1987) G proteins as regulators of ion channel function. Trends Neurosci. 10: 241-244.

Enyeart, J. J., T. Aizawa, and P. M. Hinkle (1985) Dihydropyridine $\mathrm{Ca}^{2+}$ antagonists: Potent inhibitors of secretion from normal and transformed pituitary cells. Am. J. Physiol. 248: C510-C519.

Epstein, M. L., and J. H. Dahl (1987) Neurons of the avian ciliary ganglion contain somatostatin. Soc. Neurosci. Abstr. 13: 683.

Erichsen, J. T., A. Reiner, J. B. Cabot, and H. J. Karten (1981) Neurons of the nucleus of Edinger-Westphal are the source of enkephalinergic and substance $\mathbf{P}$ containing terminals in the avian ciliary ganglion. Soc. Neurosci. Abstr. 7: 733.

Erichsen, J. T., H. J. Karten, W. D. Eldred, and N. C. Brecha (1982) Localization of substance P-like and enkephalin-like immunoreactivity within preganglionic terminals of the avian ciliary ganglion: Light and electron microscopy. J. Neurosci. 2: 994-999.

Frederickson, R. C., and C. Pinsky (1971) Morphine impairs acetylcholine release but facilitates acetylcholine action at a skeletal neuromuscular junction. Nature [New Biol.] 231: 93-94.

Gilman, A. G. (1984) G proteins and dual control of adenylate cyclase. Cell 36: 577-579.

Gray, D. B. (1986) An analysis of target properties and their trophic influence upon cholinergic metabolism of cultured avian ciliary ganglion. Ph.D. Dissertation, The University of Connecticut.

Gray, D. B., and G. Pilar (1987) ACh release in the avian choroid coat is inhibited via a $G$ protein mediated mechanism. Soc. Neurosci. Abstr. 13: 790.

Gray, D. B., M. Ford, and G. Pilar (1986) Differential opioid expression in cholinergic ciliary neurons in vivo and in vitro. Soc. Neurosci. Abstr. 12: 1008.

Gross, R. A., and R. L. MacDonald (1987) Dynorphin A selectively reduces a large transient (N-type) calcium current of mouse dorsal root ganglion neurons in cell culture. Proc. Natl. Acad. Sci. USA 84 . 5469-5473.

Guillemin, R. (1976) Somatostatin inhibits the release of acetylcholine induced electrically in the myenteric plexus. Endocrinology 99: 16531654.

Hescheler, J., W. Rosenthal, W. Trautwein, and G. Schultz (1987) The GTP-binding protein, $\mathrm{G}_{0}$, regulates neuronal calcium channels. Nature 325: 445-447.

Hescheler, J., W. Rosenthal, K. D. Hinsch, M. Wulfern, W. Trautwein, and G. Schultz (1988) Angiotensin II-induced stimulation of voltage-dependent $\mathrm{Ca}^{2+}$ currents in an adrenal cortical cell line. J. EMBO 7:619-624.

Hirning, L. D., A. P. Fox, F. W. McClesky, B. M. Olivera, S. A. Thayer, R. J. Miller, and R. W. Tsien (1988) Dominant role of N-type $\mathrm{Ca}^{++}$ channels in evoked release of norepinephrine from sympathetic neurons. Science 239: 558-561.

Holz, G. G., K. Dunlap, and R. M. Kream (1988) Characterization of the electrically evoked release of substance $\mathrm{P}$ from dorsal root ganglion neurons: Methods and dihydropyridine sensitivity. J. Neurosci. 8: 463-471.

Kaczmarek, L. K. (1987) The role of protein kinase C on the regulation 
of ion channels and neurotransmitter release. Trends Neurosci. 10: 30-34.

Katayama, Y., and S. Nishi (1984) Sites and mechanisms of actions of enkephalin in the feline parasympathetic ganglion. J. Physiol. (Lond.) 351: 111-121.

Litosch, I. (1987) Regulatory GTP-binding proteins: Emerging concepts on their role in cell function. I.ife Sci. 41: 251-258.

Logothetis, D. E., Y. Kurachi, J. Galper, E. J. Neer, and D. E. Clapham (1987) The $\beta \gamma$ subunits of GTP-binding proteins activate the muscarinic $\mathrm{K}^{+}$channel in heart. Nature $325: 321-326$.

Lundberg, J. M. (1981) Evidence for vasoactive intestinal polypeptide and acetylcholine in neurons of cat exocrine glands. Morphological, biochemical, and functional studies. Acta Physiol. Scand. Suppl. 496: $1-57$.

Lundberg, J. M., A. Anggard, J. Fahrenkrug, T. Hökfelt, and V. Mutt (1980) Vasoactive intestinal peptide in cholinergic neurons of exocrine glands: Functional significance of coexisting transmitters for vasodilation and secretion. Proc. Natl. Acad. Sci. USA 77: 16511655 .

Margiotta, J. F., and-D. K. Berg (1986) Enkephalin and substance P modulate synaptic properties of chick ciliary ganglion neurons. $J$. Neurosci. 6: 946-957.

Marx, J. L. (1987) Receptors highlighted at NIH symposium. Science 238: 615-616.

Meriney, S. D., and G. Pilar (1987) Cholinergic innervation of the smooth muscle cells in the choroid coat of the chick eye and its development. J. Neurosci. 7: 3827-3839.

Michaelson, D. M., G. McDowall, and Y. Sarne (1984a) Opiates inhibit acetylcholine release from Torpedo nerve terminals by blocking $\mathrm{Ca}^{++}$influx. J. Neurochem. 43: 614-618.

Michaelson, D. M., G. McDowall, and Y. Sarne (1984b) The Torpedo electric organ is a model for opiate regulation of acetylcholine release. Brain Res. 305: 173-176.

Miller, R. J. (1987) Multiple calcium channels and neuronal function. Science 235: 46-52.

Miller, R. J. (1988) G proteins flex their muscles. Trends Neurosci. 11: 3-6.

Montz, H., G. Davis, S. Skaper, M. Manthorpe, and S. Varon (1985) Tumor-promoting phorbol diester mimics two distinct neuronotrophic factors. Dev. Brain Res. 23: 150-154.

Moore, S. D., S. G. Madamba, M. Joels, and G. R. Siggins (1988) Somatostatin augments the M-current in hippocampal neurons. Science 239: 278-280.

Mudge, A. W., S. Leeman, and G. D. Fischbach (1979) Enkephalin inhibits release of substance $P$ from sensory neurons in culture and decreases action potential duration. Proc. Natl. Acad. Sci. USA 79: 526-530.

Nicoll, R. A. (1988) The coupling of neurotransmitter receptors to ion channels in the brain. Science 241: 545-551.

Nicoll, R. A., C. Schenker, and S. E. Leeman (1980) Substance P as a transmitter candidate. Annu. Rev. Neurosci. 3: 227-268.

North, R. A. (1986) Opioid receptor types and membrane ion channels. Trends Neurosci. 9: 114-117.

Pang, D. C., and N. Sperelakis (1983a) Nifedipine, diltiazem, bepridil and verapamil uptakes into cardiac and smooth muscles. Eur. J. Pharmacol. 87: 199-207

Pang, D. C., and N. Sperelakis (1983b) Uptake of $\left({ }^{3} \mathrm{H}\right)$ nitrendipine into cardiac and smooth muscles. Biochem. Pharmacol. 32: 16601663.

Paton, W. D. M. (1957) The action of morphine and related substances on contraction and acetylcholine output of coaxially stimulated guinea pig ileum. Br. J. Pharmacol. 11: 119-127.

Perney, T. M., L. D. Hirning, S. F. Leeman, and R. F. Miller (1986) Multiple calcium channels mediate neurotransmitter release from peripheral neurons. Proc. Natl. Acad. Sci. USA 83: 6656-6659.

Pert, C. B., and S. H. Snyder (1974) High affinity transport of choline into the myenteric plexus of the guinea pig. J. Pharmacol. Exp. Ther. 191: 102-108.

Pilar, G., R. Beach, K. Vaca, and J. Suszkiw (1978) Control of acetylcholine synthesis in motor nerve terminals. In Cholinergic Mechanisms in Psychopharmacology, D. J. Jenden, ed., pp. 481-496, Plenum, New York

Pilar, G., J. B. Tuttle, and K. Vaca (1981) Functional maturation of motor nerve terminals in the avian iris: Ultrastructure, transmitter metabolism and synaptic reliability. J. Physiol. (Lond.) 321: 175193.

Pilar, G., J. B. Tuttle, and L. Landmesser (1982) Neuromuscular independence during development. In Disorders of the Motor Unit, D. L. Schotland, ed., Wiley, New York.

Potter, L. T., and W. Murphy (1967) Electrophoresis of acetylcholine, choline and related compounds. Biochem. Pharmacol. 16: 1386-1388.

Rane, S. G., G. G. Holz IV, and K. Dunlap (1987) Dihydropyridine inhibition of neuronal calcium current and substance $P$ release. Pfluegers Arch. 409: 361-366.

Role, L. (1984) Substance P modulation of acetylcholine-induced currents in embryonic chicken sympathetic and ciliary ganglion neurons. Proc. Natl. Acad. Sci. USA 81: 1924-1928.

Sagar, S. M., D. Landry, W. J. Millard, T. M. Badger, M. A. Arnold and J. B. Martin (1982) Depletion of somatostatin-like immunoreactivity in the rat central nervous system by cysteamine. J. Neurosci. 2: $225-231$.

Sanguinetti, M. C., and R. S. Kass (1984) Voltage-dependent block of calcium channel current in the calf cardiac Purkinje fiber by dihydropyridine calcium channel antagonists. Circ. Res. 55: 336-348.

Scott, R. H., and A. C. Dolphin (1987) Activation of a G protein promotes agonist responses to calcium channel ligands. Nature 330 : $760-762$.

Sekar, M. C., and L. E. Hokin (1986) The role of phosphoinositides in signal transduction. J. Membr. Biol. 89: 193-210.

Shapira, R., S. D. Silberberg, S. Ginsberg, and R. Rahamimoff (1987) Activation of protein kinase $\mathrm{C}$ augments evoked transmitter release. Nature 325: 58-60.

Suszkiw, J., and G. Pilar (1976) Selective localization of a high affinity choline uptake system and its role in ACh formation in cholinergic nerve terminals. J. Neurochem. 26: 1133-1138.

Suszkiw, J. B., M. E. O'Leary, M. M. Murawsky, and T. Wang (1986) Presynaptic calcium channels in rat cortical synaptosomes: Fast-kinetics of phasic calcium influx, channel inactivation, and relationship to nitrendipine receptors. J. Neurosci. 6: 1349-1357.

Takahashi, M., and A. Ogura (1983) Dihydropyridines as potent calcium channel blockers in neuronal cells. FEBS Lett. 152: 191-194.

Tsunoo, A., M. Yoshii, and T. Narahashi (1986) Block of calcium channels by enkephalin and somatostatin in neuroblastoma-glioma hybrid NG108-15 cells. Proc. Natl. Acad. Sci. USA 83: 9832-9836.

Turner, T. J., and S. M. Goldin (1985) Calcium channels in rat brain synaptosomes: Identification and pharmacological characterization. J. Neurosci. 5: 841-849.

Vaca, K. W. (1980) Regulation of acetylcholine synthesis and its relation to the synaptic activity of motor nerve terminals. Ph.D. Dissertation, The University of Connecticut.

Vaca, K., and G. Pilar (1979) Mechanisms controlling choline transport and acetylcholine synthesis in motor nerve terminals during electrical stimulation. J. Gen. Physiol. 73: 605-628.

Wanke, E., A. Ferroni, A. Malgaroli, A. Ambrosini, T. Pozzan, and J. Meldoleski (1987) Activation of a muscarinic receptor selectively inhibits a rapidly inactivated $\mathrm{Ca}^{++}$current in rat sympathetic neurons. Proc. Natl. Acad. Sci. USA 84: 4313-4317.

Weill, C. L. (1987) The prevention of natural motoneuron cell death by somatostatin. Soc. Neurosci. Abstr. 13: 923.

Worley, P. F., J. M. Baraban, M. McCarren, S. Snyder, and B. Alger (1987) Cholinergic phosphatidylinositol modulation of inhibitory, G protein-linked, neurotransmitter actions: Electrophysiological studies in rat hippocampus. Proc. Natl. Acad. Sci. USA 84: 3467-3471.

Yamamoto, M. A., A. M. Boyer, J. E. Crandall, M. Edwards, and H. Tanaka (1986) Distribution of stage specific neurite associated proteins in the developing murine nervous system recognized by a monoclonal antibody. J. Neurosci. 6: 3576-3594.

Yamashita, N., I. Kojima, N. Shibuya, and E. Ogata (1987) Pertussis toxin inhibits somatostatin-induced $\mathrm{K}^{+}$conductance in human pituitary tumor cells. Am. J. Physiol. 253: E28-E32.

Yatani, A., J. Codina, A. M. Brown, and L. Birnbaumer (1987a) Direct activation of mammalian atrial muscarinic potassium channels by GTP regulatory protein $\mathrm{G}_{\mathrm{k}}$. Science 235: 207.

Yatani, A., J. Codina, Y. Imoto, J. P. Reeves, L. Birnbaumer, and A. M. Brown (1987b) A $G$ protein directly regulates mammalian cardiac calcium channels. Science 238: 1288-1291. 